\title{
THE RELATIONSHIP BETWEEN TOLERANCE OF AMBIGUITY AND CREATIVITY IN ARCHITECTURAL DESIGN STUDIO
}

\author{
Naiera Ebrahim MAHMOUD (D) ${ }^{*}$, Shaimaa Mohamed KAMEL (D, \\ Tamer Samir HAMZA (D) \\ Faculty of Engineering, Department of Architecture, Ain Shams University, \\ 1 Elsarayat Str., Abbaseya, 11517 Cairo, Egypt
}

Received 19 March 2019; accepted 11 February 2020

\begin{abstract}
Creativity is a cognitive ability that enables individuals to come up with both original and functional ideas and products. As architectural design requires producing aesthetic and practically useful solutions, it is a primary concern to enhance creativity in design disciplines. Many theorists argued that design is a non-linear process and many components of design problems are not clear at the beginning. At the start of the process, designers are always working at the periphery of a solution space where there is less coherence and more ambiguity. Thus, they must deal with a lot of ambiguity in every design situation. These states of uncertainty and confusion can be annoying for architecture students. On the other hand, tolerance of ambiguity is a personality trait that has been linked to creative thinking. Therefore, this paper attempts to investigate the correlation between tolerance of ambiguity of architectural students and their creativity via a qualitative study. The researchers implemented a mixed-method approach and recruited 18 architecture students. The results from this study revealed that there is a significant correlation between students' creative thinking abilities and their tolerance for ambiguity. Our results also indicated that there is no statistically significant correlation between students' tolerance of ambiguity and their design creativity.
\end{abstract}

Keywords: architecture students, creativity, design problems, design process, tolerance of ambiguity.

\section{Introduction}

Architecture discipline is one of the fields that require developing a special set of skills. Through their education, students learn two types of knowledge: theoretical knowledge and practical knowledge. The latter entails soft skills such as drawing and critical thinking skills. As for the former, it represents the theories, facts, and basics concerning the architectural field. The core of architectural education is the design activity. Design is usually associated with originality; hence, creativity is considered a key element in design education. In the design studio, students learn how to navigate and solve different design problems. These problems are classified as ill-defined or wicked problems because both the goal and the route

*Corresponding author. E-mail: naieraebrahim@eng.asu.edu.eg 
to achieve that goal are not clearly expressed (Lawson, 2005). In addition, the information needed to solve such problems is not always available for the designer to begin with. In addition, the nature of design problems engenders a lot of ambiguity and uncertainty. During the design process, and especially at the beginning, students face a fuzzy period where they must be patient until a creative idea emerges. In this period, students may experience anxiety and stress which can affect the creativity of their products (Belluigi, 2013). Therefore, students can benefit from learning how to tolerate this ambiguity. Indeed, tolerance of ambiguity is considered one of the characteristics of the creative personality (Merrotsy, 2013). Thus, this trait may enhance the students' ability to manage the design process.

The goal of this paper is to investigate the construct of ambiguity tolerance and examine the theories and studies demonstrating its significance to creativity. In addition, this study is exploratory in nature as it seeks to explore the correlation - if any - between tolerance of ambiguity and students' design creativity. As far as we can ascertain, no research has been done relating tolerance of ambiguity and creativity to architectural design except one study that came to mention this relationship theoretically (Mahdizadeh Hakak et al., 2014). Hence, results from our study can provide an insight regarding the importance of ambiguity tolerance to design education. The aim of this paper is to answer the following questions:

- Why tolerance of ambiguity can be considered significant to design process?

- Is there a relation between students' tolerance of ambiguity and their creativity?

In order to investigate these questions, a qualitative study is conducted to investigate the impact of tolerance of ambiguity on the creativity of design students. As previous studies argued that design literature lacks validated theoretical models of uncertainty perception in design (Cash \& Kreye, 2018); there is a need for more elaborate theory building regarding the three core elements; creativity, uncertainty/ambiguity tolerance, and architectural design. The main contribution of this research lies in trying to provide empirical evidence that highlights the role of ambiguity and uncertainty in students' experiences. Thus, this paper postulates that students with high tolerance of ambiguity will generate more creative ideas and solutions.

\section{Literature review}

\subsection{Architectural design process}

Architecture is one of the most centrally placed fields in the spectrum of design. Many researchers and theorists have tried to define and analyze the design process in order to capture its essence. One of these researchers is Bryan Lawson who defined design process as a "Sophisticated mental process capable of manipulating many kinds of information, blending them all into a coherent set of ideas and finally generating some realization of those ideas" (Lawson, 2005, p. 14). This means that designers must have the ability to comprehend different types of information in a limited time in order to generate the optimum solution. Donald A. Schon also described design as a reflective conversation between the designer and the problem/situation at hand. By doing this, designers can frame the problem, generate moves toward the solution, and reflect on these moves which in turn can alter the perception of both the problem and the solution (Schon, 1986; Hokanson \& Gibbons, 2014). Therefore, in 
order to deal with design problems, architectural students need to embrace this distinctive design behavior.

Walter Ralph Reitman argued that design problems have ambiguous specifications of their start state, goal state, and the path that leads to the final/goal state (Goel \& Pirolli, 1992, p. 397). Design problems are, in fact, categorized as ill-defined or wicked due to the following characteristics (Buchanan, 1992):

- Design problems have no definitive formulation. Instead, every formulation of a design problem corresponds to a formulation of a solution;

- Design problems have no stopping rules;

- Design problems have no true or false solutions, only good or bad;

- Design problems have no exhaustive list of operations to solve it;

- Every design problem has more than one possible explanation;

- Solutions to design problems have no definitive test.

It is clear that many components of design problems are not clear at the beginning and cannot emerge until some attempts are made to generate solutions. Designers are always working at the periphery of a solution space where there is less coherence and more ambiguity and uncertainty. In fact, uncertainty in the design process is well documented in both the design literature and creativity literature (Osmond et al., 2009). During the design process, designers are required to navigate different variables that are characterized by some degree of uncertainty and are pushed to proceed amidst the vagueness of the process (Daalhuizen et al., 2009). Trying to explain this dilemma, Mike Tovey states:

"It is possible that the incubation periods, that time of apparent in activity during which the designer's brain furiously grapples with the problem, is simply the period during which the two halves of the brain are out of touch or unable to agree. But, contrast the moment when they do suddenly come into alignment would be the classic 'eureka' point" (Osmond et al., 2009, p. 172).

Students, then, need to be able to work with design uncertainty without being paralyzed by hesitation. They must accept this uncomfortable period in order to develop successfully creative solutions.

\subsection{Creative process}

Creativity, as a distinct research field, has been studied in many ways. Creativity can be described as the ability to produce a work that is both novel/original and valuable/useful with respect to the given constraints. It involves encountering conflicts, gaps, and paradoxes. It is widely believed that creativity depends on the presence of several factors that interact with each other such as individuals' knowledge, personality traits, cognitive style, and motivation (Zenasni et al., 2008). Moreover, much research has stated that creativity consists of four components (the 4Ps): the creative person, product, press, and process. The creative person (designer) is someone who has a distinctive set of mental abilities that enables him/ her to accomplish creative solutions (Ward et al., 1995). Furthermore, according to Graham Wallas, the creative process (design process) includes four stages: preparation, incubation, illumination, and verification. Preparation stage is about understanding the task at hand and gathering the needed information to solve the problem. In incubation stage, the conscious 
mind must stop focusing on the problem allowing the subconscious to be in charge. Usually after a long unconscious work a sudden insight emerges, which marks the illumination stage. The verification stage is based on verifying and assessing the idea/solution with respect to the problem and its requirements. In addition, it is well established that during the life of any creative process, ambiguity and uncertainty start at their highest values and continue to decrease while approaching the end of the process (Arquero \& Tejero, 2009). From this review, it can be deduced that ambiguity lies at the centre of every creative process. In fact, creative work puts high demand on individual's ability to accept feelings of anxiety, uncertainty, and psychological discomfort and to avoid jumping to easy and simple answers (Stoycheva, 2003; Wallas, 2014).

\subsection{Tolerance of ambiguity}

Tolerance/intolerance of ambiguity is considered a personality trait that describes person's perception and ability in dealing with ambiguous situations or stimuli. Individuals who are tolerant of ambiguity find these situations interesting and desirable. In contrast, individuals who are intolerant of ambiguity feel stressed, anxious, and irritated in ambiguous situations and react prematurely. Research has emphasized that individuals with high ambiguity tolerance are more likely to excel at complex problem solving situations, divergent thinking tasks, and brainstorming (Jonassen \& Grabowski, 1993; Griffin \& Care, 2015; Zenasni et al., 2008). In fact, a great amount of research claimed that tolerance of ambiguity is a factor of creative thinking. This assertion is based on the idea that ambiguity tolerance will allow individuals to continue to struggle with complex problems, to stay open minded, and increase the probability of finding novel solutions (Zenasni et al., 2008). Mark A. Runco, for example, argued that creative personality is a combination of the following: autonomy, flexibility, preference for complexity, openness to experience, risk taking, curiosity, playfulness, and tolerance of ambiguity (Merrotsy, 2013, p. 232). Furthermore, the psychologist Frank Farley argued that a creative person is one who "[...] lives on the edge of uncertainty, thrives on novelty, and is tolerant of ambiguity” (Anderson, 2010, p. 9). Joy Paul Guilford, who had an enormous influence on the psychology of creativity, has found a positive correlation between tolerance of ambiguity and creativity of visual arts students (1950). In fact, there is a tremendous amount of studies that demonstrated the significant correlation between ambiguity tolerance of their participants and their performance in creative problem solving abilities (Comadena, 1984; Allwood \& Selart, 2001; Wu et al., 2016).

With reference to designers, they are always working under conditions of complexity and uncertainty. As ambiguous situation is defined as "one which cannot be adequately structured or categorized by the individual because of lack of sufficient cues" (Budner, 1962, p. 30), it resembles almost every design situation. Expert designers know that a certain amount of chaos and doubt is necessary in the design process; still, students find states of uncertainty threatening and annoying (Litchfield, 2016). Their experience with previous educational systems made them accustomed to deal with clear goals that needed structured ways to achieve them. They often seek clarity; however, a central tenet of design pedagogy is the centrality of ambiguity to the creative process (Austerlitz et al., 2008). A recent research argued that tolerance of ambiguity/uncertainty is a key skill for designers. However, there is limited prior 
research examining ambiguity tolerance and creativity with respect to engineering. One of these studies aimed at examining the relation between ambiguity tolerance of engineering students and their creativity. The results indicated that the more students are tolerant to ambiguity, the more they generate original ideas (Balgiu, 2014). Another study examining the factors that affect creative concept selection in engineering design teams was published in 2016. The students' risk and ambiguity aversion was measured. Then they attended a design session and were required to design a novel device to forth milk. The findings indicated that teams who score more on ambiguity tolerance tended to generate concepts that are more creative (Toh \& Miller, 2016). Hence, it is argued that art and design pedagogies must offer ways to approach complexity and interact with openness and uncertainty to enable the graduates to negotiate the ambiguity of design situations (Austerlitz et al., 2008).

\section{Methodology}

In order to address the research hypothesis an exploratory qualitative study was conducted at one of the well knowns and old architecture schools recruiting a group of first and secondyear architecture students. These two academic years have been specifically chosen to capture the students' performance and personal traits before they are altered by the education systems. The researcher has used mixed-method approach where quantitative and qualitative instruments are implemented. Questionnaires, a design task, and in-depth interviews have been used in order to develop a complete picture and deeper understanding of the relation between the study variables.

\subsection{Participants}

Through purposeful sampling, 18 architectural students were chosen. There were 4 male and 14 female students, in which half of them were first-year students and the other half were second-year students. The researcher selected them based on their academic performance in design related courses; hence, every group of students was selected so that they cover the following categories: A (excellent), B (very good), or C (good), in which every three students fall in one category. Each student was evaluated based on the mean grade of his past design projects, for second year, or his mean grade in Visual Design course, for first year. Noteworthy, at the time of the study, first year students were completing their first design project, while second-year students were completing their fourth design project.

\subsection{Variables and measures}

In order to investigate the relation between tolerance of ambiguity and students' creativity, several measures were used. These measures are described in detail in the following sections.

\subsubsection{Tolerance of ambiguity}

In 1949, Else Frenkel-Brunswik (1908-1958), a Polish-Austrian psychologist, was the first to introduce the construct of intolerance of ambiguity as an emotional and perceptual personality variable (Arquero \& Tejero, 2009). With respect to problem solving, intolerance of 
ambiguity can be defined as framing problems rigidly into fixed categories, selecting solutions at an early stage, and adopting a premature closure. Based on the work of FrenkelBrunswik, many researchers like Stanley Budner, Robert W. Norton and A. P. MacDonald have developed several questionnaires to measure intolerance/tolerance of ambiguity (Arquero \& Tejero, 2009). All these researchers sought to refine the construct, yet the core definition remains consistent. Finally, Herman, Stevens, Bird, Mendenhall, and Oddou (2010) proposed a new measure for tolerance of ambiguity in a research paper published in 2010 . Their 12-item final scale is designed to be scored on a 5-point Likert scale, ranging from " 1 : strongly agree" to "5: strongly disagree" with "3: neither agree nor disagree" option in the middle (see the Appendix). Higher scores represent more ambiguity tolerance where lowest possible score $=12$ and highest possible score $=60$. Based on the previous discussion, Herman, Stevens, Bird, Mendenhall and Oddou scale was chosen to be administered to the students due to two reasons:

- The scale is not too tall; hence, the cognitive burden placed on participants can be minimized;

- The wording of the scale statements is friendlier and can be easily comprehended unlike other tolerance of ambiguity scales.

\subsubsection{Students' creativity}

Creativity is considered a cornerstone in architecture discipline; hence, most of university programs are based on considering creative thinking as an important graduate attribute (Casakin, 2008). Regarding assessing creativity, there is much debate on whether creativity is a generalized ability or domain specific. The first assumption is based on the notion that creativity can be measured as a way of thinking; hence, several divergent thinking tests and personality inventories have been developed such as Torrance Test of Creative Thinking (TTCT). In fact, TTCT is one of the most widely used assessment of creative talent (Chan, 2015). Based on Guilford' theory of divergent thinking, this test has been used for more than 40 years in scientific research. It was used in assessing the creativity of architecture students in several studies (Ayyıldız Potur \& Barkul, 2006, 2009; Hamza \& Hassan, 2016; Cho, 2012). Creativity of students; hence, can be assessed in terms of their divergent thinking skills. That is why TTCT will be implemented in this study. The figural TTCT (Form B) will be used since it is widely known to be unbiased in terms of culture, gender, language, and socioeconomic status (Kim, 2011). The figural Form B consists of three activities: picture construction activity (1), picture completion activity (2), and circles activity (3). The first activity gives the participant a curvilinear shape and asks him/her to think of a picture or an object that can be drawn with this shape as a part. The second activity consists of 10 meaningless figures and asks the participant to add lines to create meaningful objects. As for the third activity, the participant is presented with two pages of circles in which he/she should add lines to make recognizable objects/pictures.

TTCT measures the following five norm-referenced measures (Tan, 2007):

- Fluency: the number of meaningful and valid responses (estimated for activity 2 and 3);

- Originality: the number of statistically infrequent ideas (estimated for activity 1, 2, and 3); 
- Elaboration: the number of the details added beyond the minimum details necessary for the basic response (estimated for activity 1 and 2);

- Abstractness of titles: measures the degree a title is expressed beyond obvious labelling of the objects drawn (estimated for activity 1, 2, and 3);

- Resistance to premature closure: the degree of psychological openness, the ability to keep open in processing information and consider a variety of concepts and perspectives (estimated for activity 2).

TTCT is concerned with divergent thinking; however, convergent thinking is also important in generating the best-optimized solution. Runco stated that: "Originality is vital but must be balanced with fit and appropriateness" (Runco \& Jaeger, 2012, p. 92). TTCT does not measure appropriateness, which is a key element in evaluating architectural design solutions. Here lies the significance of the second assumption, which contends that creativity is domain specific and that measures of aptitude in specific areas or assessments of certain products are more convenient in assessing creativity. On the other hand, the traditional way to assess creativity of students' products in academia is based on the agreement among the evaluators that relies on both their understanding of creativity and their subjective judgment (Casakin \& Kreitler, 2008). Hence, and based on the previous debate, the researchers decided to use a design task along with TTCT to assess architecture students' creativity. The researchers selected a simple design problem to resemble the typical projects usually assigned to first and secondyear students. It was stated as follows: You are required to design an outdoor seat/bench that can offer a relaxation spot for the students. It can accommodate one or two students and should provide protection from the sun. Your design must be attractive and elegant, as it will be placed in the northern outdoor space of our campus. Present your idea/design drawings (free hand sketches... plan... section... 3D, as you like) on A4 Canson sheets.

\subsection{Procedure}

At the beginning of the study, the students were invited to participate in a competition to design street furniture that can be installed in Faculty of Engineering, Ain Shams University, Egypt, campus. They were told that participation is voluntary and those who will participate will receive a gift at the end of the experiment. Participants attended a session at one of the lecture halls in the architectural department building. There was a session for first-year students and another one for second-year students on a separate day. Both of TAS and TTCT were administered to the students at the same session. The researcher decided to administer TTCT at the beginning of the session in order for the students to be in their full concentration. After collecting both of the tests from the students, the researcher explained the design task and asked the students to deliver their designs after a week. After receiving students' designs, they were assessed independently by three design staff members who were contacted to participate in the study as jurors. They were architecture professors working at the architectural department with experience ranging from 18 to 38 years.

Moreover, in order to explore students' feelings and attitudes towards the ambiguity and uncertainty inherent in the design process, the researcher conducted in-depth interviews with four students in each year $(n=8)$. One of the advantages of implementing open-ended questions is giving the students the opportunity to respond in their own words. In addition, it 
gives the researcher the ability to use probes to encourage them to elaborate in their answers, which eventually can elicit a vivid picture of students' experiences (Mack et al., 2005). Hence, students who attained the highest and lowest values in both TAS score and design grades were selected to be interviewed. The researcher posed the following questions:

- In each project, and after conducting your research, explain what do you do to proceed in your design;

- Describe how you feel at the beginning of the design process. Is there a time when you felt discouraged, that you are not able to do anything, that the road ahead is not clear? Explain;

- How did you handle these situations?

- At the beginning, do you commit yourself to the first idea that appear to you and try to develop it, or do you wait a bit longer to generate more alternatives and then choose one of them? Elaborate how and why;

- Explain your opinion about whether uncertainty and ambiguity constitute an essential part in the design process or not.

The interviews were conducted at the same hall where the first part of the study has taken place. All the conversations have been tape recorded, and then each interview was converted in a typed transcript form by the researcher.

\section{Results}

\subsection{Analysis of the design task and applied questionnaires}

Regarding the design task, the evaluations of the three jurors were obtained, then, the mean grade for each student was estimated. Noteworthy, the professors were informed to rely on assessing both the artistic/aesthetic and functional aspects of the presented designs. However, students' average grades on the design task did not show the expected pattern with respect to their precedent design performance due to the inappropriateness of the timing of the experiment with respect to students' academic year. They were approaching the end of the semester; hence, they were busy with their exams and submissions. Therefore, the researchers decided to use the grades of their design projects as an indication for their design creativity instead of the design task as it did not reflect the true performance of almost half of the students ( $40 \%$ of them). The students were working on these projects for a whole semester. The project was a residential villa for first-year students and a residential-managerial tower for second-year students.

As for TTCT, the researcher relied on the scoring manual for estimating both the raw score and standard score for the five norm-referenced measures. Then, the mean value of the calculated standard scores was obtained for each student. In order to examine the relation between students' design (project) grades and their TTCT scores, the researcher applied a descriptive analysis using SPSS T-Test (correlation-bivariate test) between the two variables and the result is presented in the Table 1. As shown in the table, the correlation coefficient, highlighted in red, has a positive value that indicates a relatively weak positive relation between students' TTCT scores and project grades. However, the value of Sig. $(2$-tailed $=0.135)$ is higher than alpha level $(0.05)$ which means that we can accept the 
null hypothesis stating that there is no statistically significant correlation between TTCT scores and project grades.

Table 1. The results of SPSS T-Test between students' Torrance Test of Creative Thinking results and project grades (source: created by authors)

\begin{tabular}{|l|l|c|c|}
\hline \multicolumn{4}{|c|}{ Correlations for the sample } \\
\hline \multicolumn{2}{|c|}{} & $\begin{array}{c}\text { Torrance Test of } \\
\text { Creative Thinking } \\
\text { scores }\end{array}$ & $\begin{array}{c}\text { 2nd term project } \\
\text { grades }\end{array}$ \\
\hline $\begin{array}{l}\text { Torrance Test of Creative } \\
\text { Thinking scores }\end{array}$ & $\begin{array}{l}\text { Pearson Correlation } \\
\text { Coefficient }\end{array}$ & 1 & .366 \\
\cline { 2 - 4 } & Sig. (2-tailed) & 18 & 135 \\
\cline { 2 - 4 } & $\mathrm{N}$ & .366 & 1 \\
\hline 2nd term project grades & $\begin{array}{l}\text { Pearson Correlation } \\
\text { Coefficient }\end{array}$ & .135 & 18 \\
\cline { 2 - 4 } & Sig. (2-tailed) & 18 & 18 \\
\cline { 2 - 4 } & $\mathrm{N}$ & 18 & 18 \\
\hline
\end{tabular}

In exploring the relation between students' TAS scores and their creativity measured by their project grades, the following Table 2 shows that there is no statistically significant correlation between the students' tolerance of ambiguity and their design creativity (value of Sig. (2-tailed) is higher than 0.05).

Table 2. The results of SPSS T-Test between students' tolerance of ambiguity scores and project grades (source: created by authors)

\begin{tabular}{|c|c|c|c|}
\hline \multicolumn{4}{|c|}{ Correlations for the sample } \\
\hline & & $\begin{array}{c}\text { Tolerance of } \\
\text { ambiguity scores }\end{array}$ & $\begin{array}{l}\text { 2nd term project } \\
\text { grades }\end{array}$ \\
\hline \multirow[t]{3}{*}{ Tolerance of ambiguity scores } & $\begin{array}{l}\text { Pearson Correlation } \\
\text { Coefficient }\end{array}$ & 1 & $\overline{.0}$ \\
\hline & Sig. (2-tailed) & & .888 \\
\hline & $\mathrm{N}$ & 18 & 18 \\
\hline \multirow[t]{3}{*}{ 2nd term project grades } & $\begin{array}{l}\text { Pearson Correlation } \\
\text { Coefficient }\end{array}$ & -.036 & 1 \\
\hline & Sig. (2-tailed) & .888 & \\
\hline & $\mathrm{N}$ & 18 & 18 \\
\hline
\end{tabular}

Moreover, the results obtained from SPSS T-Test revealed that there is a statistically significant correlation between students' creativity measured by their divergent thinking ability (TTCT) and their tolerance of ambiguity as shown in Table 3 (value of Sig. (2-tailed) is lower than 0.05). This assures our hypothesis that tolerance of ambiguity can be an important factor at the early stage of any design activity where divergent thinking is most needed. 
Table 3. The results of SPSS T-Test between students' tolerance of ambiguity scores and Torrance Test of Creative Thinking results (source: created by authors)

\begin{tabular}{|l|l|c|c|}
\hline \multicolumn{3}{|c|}{ Correlations for the sample } \\
\hline \multicolumn{2}{|l|}{} & $\begin{array}{c}\text { Torrance Test of } \\
\text { Creative Thinking } \\
\text { scores }\end{array}$ & $\begin{array}{c}\text { Tolerance of } \\
\text { ambiguity scores }\end{array}$ \\
\hline $\begin{array}{l}\text { Torrance Test of Creative } \\
\text { Thinking scores }\end{array}$ & $\begin{array}{l}\text { Pearson Correlation } \\
\text { Coefficient }\end{array}$ & 1 & $.525^{\star}$ \\
\cline { 2 - 4 } & Sig. (2-tailed) & & .025 \\
\cline { 2 - 4 } & $\mathrm{N}$ & 18 & 18 \\
\hline Tolerance of ambiguity scores & $\begin{array}{l}\text { Pearson Correlation } \\
\text { Coefficient }\end{array}$ & $.525^{*}$ & 1 \\
\cline { 2 - 4 } & Sig. (2-tailed) & .025 & 18 \\
\cline { 2 - 4 } & $\mathrm{N}$ & 18 & \\
\hline
\end{tabular}

*. Correlation is significant at the 0.05 level (2-tailed).

\subsection{Analysis of in-depth interviews}

As for the interviews, the transcripts have been coded according to students' responses to each question in order to grasp the emerging salient themes. By coding, the researcher divided each interview into segments; named them in specific terms (i.e. giving them codes), and built categories that can help in developing abstract ideas for interpreting each segment into meanings and actions. The researcher coded the eight transcripts manually relying on coding procedures presented in Kathy Charmaz's (2006) book. Then, the responses for each question were obtained from the transcripts and categorized. In addition, a comparison has been made between the responses of first and second-year students in order to capture and highlight the variance. The following section will provide the results of this analysis.

\subsubsection{How you begin your design process?}

Regarding starting the design process, students' responses were attributed to one of the following categories: (1) start searching for idea, concept, and inspiration ( $\mathrm{n}=3$ (first year (F. Y.) + 1 (second year (S. Y.)), (2) begin imposing some design constraint (primary generator) $(\mathrm{n}=1$ (S. Y.)), (3) analyze the data gathered from the research $(\mathrm{n}=2(\mathrm{~S}$. Y.) ), or (4) wait for guidance and feedback from the staff ( $n=1$ (F. Y.)). Regarding the first category, the students explained that in order to begin with their design they must have a concept that can lead them through the whole process and give their designs identity. In the second category, students initiate thinking about one of their design aspects, that is, to impose a primary generator such as selecting the architectural style or the type of lines that will be implemented (straight lines or curves...). Other responses fell in the third category, in which students start by analyzing their available resources of data (researches). Noteworthy, submitting a research at the beginning of projects is a program requirement. These researches usually include standard data of the building type and a group of analyzed similar examples. Finally, one of the 
students just waits for an input from the staff; he wanted to know how to begin or what to begin with $(3 \mathrm{D}$, layout, plans...) before exerting any effort in the design.

\subsubsection{How do you feel at the beginning of your design process? Is there a time when you felt discouraged, that you are not able to do anything, that the road ahead is not clear? Explain}

This question is twofold; hence, the responses will be divided into two parts. Regarding the first part which deals with the feelings associated with the early stage of the design process, students' responses fell into one of the following categories: (1) positive feelings like enjoyment, happiness, and excitement ( $\mathrm{n}=3$ (F. Y.) +1 (S. Y.)), (2) negative feelings like feeling lost, vulnerable, and not balanced ( $\mathrm{n}=3$ (S. Y.) +1 (F. Y.)). The first response indicates that some students feel excited and thrilled in starting the design. They explained that they are enthusiastic and eager to produce a successful design, which will be a product of their efforts (sense of pride). The rest of the students illustrated that they feel astray, disoriented, having no ground to stand on, and not knowing one's whereabouts.

As for the second part of the question, all the students assured that they experience states of not knowing, ambiguity, uncertainty, doubt, and being stuck through the design process. In fact, several studies have assured that these states are always experienced in design activities. One of these is a paper entitled “'Stuckness' in the Design Studio" and published in 1999. The study used interviews with both architecture students and recent graduates in order to better understand these states and explore its characteristics. The respondents acknowledged stuckness to be ingrained in the design process. They reported that these states caused them feelings of pressure, helplessness, and frustration (Sachs, 1999). With respect to our study, a first-year student (St. 2) stated: "When I am stuck I feel upset [...] I reach states when I am about to cry [...]". A second-year student (St. 3) describes her experience as follows: "I feel overwhelmed [...] sometimes; I lose hope [...] no use of waiting long time in this state".

Another student (St. 7) argued: "I experience nervous breakdown [...] I even feel that I must leave the department". Through the analysis of the transcripts, the researcher managed to identify students' opinions regarding the reasons behind such states. The three reasons were: (1) failure in trying to develop ideas and move to the next phase or failure in attaining a result after extended periods of searching and thinking, (2) having several choices or alternatives to select from, and (3) having insufficient data concerning any aspect/element of the designed product. Most of the students acknowledged these situations as causes for their struggle in the design process. A first-year student (St. 4) tried to explain this experience: "While designing [...] the goal is known, but the way of achieving it or the road ahead is not clear". Another student (St. 2) argued: "Sometimes, I am not able to imagine how things will work out [...]". In addition, the researcher used probes to encourage the students to reflect on their feelings in states of ambiguity and not knowing. Almost all the students argued that they experience negative feelings such as anxiety, disturbance, stress, despair, and frustration. A first-year student (St. 8) illustrated that she prefers to end these states: "Because of these feelings, I do not want to keep thinking for a long time [...] I always hope to have ideas as soon as possible". 


\subsubsection{How do you deal with states of not knowing/ambiguity/being stuck?}

The third question revealed three categories: (1) take a break and try to detach oneself from this situation ( $\mathrm{n}=1$ (F. Y.)), (2) re-search, re-think, and re-try (keep working) ( $\mathrm{n}=2$ (F. Y.) + 2 (S. Y.)), or (3) do not know what to do ( $\mathrm{n}=1$ (F. Y.) +2 (S. Y.)). Regarding the first category, the student explained that sometimes he resorts to refresh their minds by taking a walk, going to gym, or meeting friends. The second category illustrates that some students keep trying, thinking, and searching for ideas and alternatives. They re-visit their available data and resources to check if they accidently dropped some piece of information that can help them. Students of the final category demonstrated that they do not know specifically how to deal with this period. They did not manage - yet - to develop or recognize a procedure that can help them endure states of ambiguity and uncertainty.

\subsubsection{Describe your thinking pattern in searching for design ideas}

Students' responses fell into the following categories: (1) develop and work on ideas one by one ( $n=3$ (F. Y.)), (2) drop early idea/s and generate more ones ( $n=3$ (S. Y.)), (3) both of the above $(\mathrm{n}=1$ (F. Y.) +1 (S. Y.)). The first category suggests that students generate an idea, develop and work on it until facing problems in proceeding with it. Herein, most of the students abandon the first idea and search for another (better) one. Students of the second category argued that they never pursue the first idea because it always seems naive and poor. Hence, they keep generating ideas until a favorable one emerges. They also believed that more thinking would eventually produce better ideas. The final category means that students sometimes adopt the first idea to come to their minds and work on it and sometimes they drop it for subsequent ideas.

\subsubsection{Describe your opinion regarding whether ambiguity/uncertainty is inherent in any design process}

All the students demonstrated that dealing with ambiguity and being stuck is essential characteristic of any design activity. Although students differ in how they describe their experiences and opinions, using probes helped the researchers to unfold some of their deep feelings. A first-year student (St. 4) explained his opinion: "As long there are many unknowns, I think I will be confused and unbalanced [...] I will not be able to go through it (the process) easily [...]". Another student (St. 2) stated: "I think I will get stuck a lot [...] lack of necessary data and having various unknowns will result in periods of vagueness and uncertainty". Another student (St. 7) described: "I believe that if everything goes smoothly, easily, and without stumbling, there will be definitely something wrong [...] I think that in order to achieve novelty, you must suffer". Moreover, a second-year student (St. 8) borrowed an architect's statement to explain her opinion regarding the design process: "He stated that if you begin to design your project with everything clear and you know what to do in advance, do not do it [...] so I believe that part of design activity's charm lies in states of not knowing”.

It is worth mentioning that half of the students argued that duration and intensity of periods of ambiguity and states of not knowing might depend on design experience. In their opinion, these situations will be longer, more difficult, and more prevalent in case of designing unfamiliar projects in relation to familiar ones. In other words, designing new types of 
buildings or projects may be harder than designing precedent projects. They explained that trying to design a project that they designed before might be easier due to the developed repertoire regarding various design aspects such as building elements, space requirements, spatial relations, and other design fundamentals. Moreover, some of them illustrated that states of ambiguity are not just at the early stage of the design process; they exist at different points along the journey. However, they assured that it is harder and more demanding at the beginning. Another element that seemed to bother the students is the impact of time on their experience of the design process. Half of them used expressions like "limited time, there is no time for [...], do (something) to catch up with time, I wish I had more time, if it was not for time, I would [...]". Time was seen as a restriction that induces stress and anxiety in students' psyches.

In addition, the interviews helped in revealing the behavior of the students during the design process and creating an image concerning their performance. This no doubt helped the researchers in justifying the inconsistency in some of our results. For example, some students have attained high scores in ambiguity tolerance and low grades in their design projects. Another group of students has low scores in ambiguity tolerance and high grades in their projects. The researchers conducted an in-depth review of the students' responses which assisted in rationalizing such results. Concerning students who attained high TAS score but low grades on their design projects, they reported that being stuck and dealing with states of not knowing was not a bad thing. However, one of them argued that he did not know how to develop his ideas or how to replace it with a better one later in the process (St. 4 F. Y.). Another student reported that she waits long enough to generate a unique/creative concept for her project. She was having trouble in time management; accordingly, this sometimes made her fall behind her classmates (St. 8 S. Y.). As for students who attained low TAS score and high grades on design projects, states of ambiguity and confusion were annoying. One of them even stated that these situations could make her cry (St. 2 F. Y.); still, they reported seeking perfection and pursuing unique design ideas (St. 8 F. Y.).

\section{Discussion}

The goal of the present study was to examine the relation between tolerance of ambiguity and creativity in architectural design. Given that designers are always working with uncertainties and ambiguities, hence, the major concern of this study was to draw the attention to the significance of ambiguity tolerance in architecture discipline. In order to achieve this, the researchers implemented a mixed-method approach and recruited 18 architecture students who were subjected to TTCT, Herman, Stevens, Bird, Mendenhall and Oddou TAS, a design task, and in-depth interviews. The analysis revealed that there is a significant correlation between students' creativity, measured by TTCT, and their tolerance for ambiguity. In other words, students' divergent thinking ability was related to their ability to tolerate ambiguity and uncertainty. It is well established that divergent thinking goes hand in glove with convergent thinking in every creative process that results in a new idea (Glover et al., 2010). Divergent thinking is defined as the ability to generate a multiplicity of possible solutions and ideas. In contrast, convergent thinking is the ability to concentrate on finding out a single 
best solution for the problem. Hence, design creative process also depends on both of the abilities. Both kinds of thinking are needed in design (Chan, 2015; Taura \& Nagai, 2011). The student must be able to generate different ideas at the beginning of the design process. Then, he/she selects the most suitable idea with respect to the problem at hand. The above finding indicates that one of the factors that affect students' ability to diverge is the ability to stay for a while in states of ambiguity and not knowing. In other words, the ability to produce various ideas is linked to the ability of being in uncertainties, doubts, and mysteries without rushing and seeking the certainty of fact and reason.

In addition, the analysis of the transcripts revealed that most of first-year students adopt dealing with design ideas one by one unlike most of second-year students who adopt generating multiple ideas then proceed with the most appropriate/favorable one. This result is echoed in Lawson's book How Designers Think: The Design Process Demystified, where he argued that designers could be classified into two groups; some of them shift their attention to another idea when they face a dead end, while the others manage to deal with several ideas in parallel (Lawson, 2005). In fact, these results are compatible with his argument concerning young architecture students. He stated that most of them usually find difficulty in producing a range of ideas: "[...] they are locked into a solution without having a full spectrum available to judge whether that is an appropriate solution" (Lawson, 2005, p. 211). It became also clear that most of first-year students neglect the gathered data (the submitted research) and begin directly in searching for ideas. In contrast, half of second-year students cared more for analyzing the available data resources before beginning to design. This indicates that the second group is more sensitive to the value of the gathered data in the design process. Clearly, reviewing the standard data regarding the project at hand and analyzing the precedent work of similar projects is pivotal in developing a knowledge base. Young students need this knowledge to guide them in their design activities. The variance between the two groups can be justified by their educational experiences. Students' different strategies may be attributed to factors like problem scoping, information seeking, and intellectual maturity.

Moreover, states of ambiguity, uncertainty, and not knowing are acknowledged by all of the students to be inherent in the design process. They found themselves dealing with these situations every time they engage in designing. Students responses resonate with a study mentioned in Design Creativity 2010 book (Taura \& Nagai, 2011). The study argued that there are two main consequences of uncertainty for problem solvers: (1) the inability to make a decision, and (2) the need to work on the situation to progress beyond the uncertainty. They also discussed that states of uncertainty arise either from designers' lack for relevant prior experience/knowledge, or from the fuzziness of the design cues.

As for the relation between the rest of our variables, the analysis indicated that there is no statistically significant correlation between students' tolerance of ambiguity and their project grades. Although their tolerance of ambiguity was found to be significantly correlated with their creative thinking, students' project grades did not correlate with their ambiguity tolerance. This statement indicates that tolerance of ambiguity is correlated with the creativity of the students at the first part of the design process, i.e. divergent thinking phase, but is not correlated with their creativity at the second part of the process, i.e. convergent thinking phase. In other words, the analysis suggests that ambiguity tolerance can affect students' 
creative abilities at the start of the design process, but may have no impact on the process outcome/end result. This finding can be rationalized by the arguments introduced in several recent studies. In fact, a recent paper discussed that sometimes the reason behind not achieving creative solutions lies in the second phase of the design process, that is, convergent thinking. The researchers argued that designers may success in generating creative ideas in divergent thinking phase; however, they rapidly filter out these ideas in convergent thinking phase and end up with ideas that are more traditional. The researchers attributed this behavior to designers' bias against creative concepts and the uncertainty associated with it. This result may also justify the earlier findings regarding students with high TAS scores but low design grades. Actually, a recently published paper studied the ambiguity and risk aversion of 38 undergraduate engineering students and their design ability. The researchers concluded that ambiguity aversion was important in the phase of generating creative ideas but not in selecting/assessing creative ideas (a subsequent phase) (Toh \& Miller, 2016). In addition, students' project grades were not found to be significantly correlated with their divergent thinking abilities (TTCT scores). The previous justification can also help in interpreting this result. Further, as mentioned previously the design process involves both divergent thinking and convergent thinking. These two factors can jointly affect the creativity of the outcome. Moreover, other factors can contribute to students' design performance. Factors like student's background knowledge, experience, motivational aspects, and other personality traits (Gonçalves et al., 2014). All these factors combine and affect student's design performance, which can be the reason behind the indeterminacy of the previous two relations.

\section{Research limitations and future work}

As previously mentioned, there are several studies demonstrating a correlation between ambiguity tolerance and creativity; still, our results indicate that there is no significant correlation between this construct and students design creativity. This can be due to the inappropriateness of the scales developed for measuring tolerance of ambiguity with respect to architectural design. These measures need to be developed and validated for use in design disciplines. In fact, this proposition is argued in another study (Toh \& Miller, 2016). Moreover, we acknowledge that our interview results did not allow us to provide a clear-cut insight concerning the effect of design ambiguity on the students. The researchers could not conduct in-depth interviews with the rest of the students because there was a limited time before their final examinations. We hoped also to offer a fine-grained image of the procedures that students use to deal with these situations. That is why we prefer to see our results as indicative rather than being definitive.

Our findings suggest that design education needs to nurture ambiguity tolerance in the students. Still, recent research argues that little is known about the processes involved in developing tolerance for uncertainty/ambiguity. Because this ability is linked to psychological aspects, some of which involve unconscious processes, it is less visible and is more difficult to codify and articulate than the other design skills (Carabine, 2013). Further research is required in order to better examine students' attitudes toward design ambiguity and investigate the impact of these states on their design performance. Similarly, larger sample sizes and 
studying other educational levels and individual attributes may reveal a link between design creativity and tolerance of ambiguity that was not attained in this study. Our results revealed that students are aware of states of ambiguity and not knowing in different points in their design processes; however, they do not know how to deal with them. Hence, there is a need to generate and develop certain methodologies and procedures that help them cope with these situations.

\section{Conclusions}

This paper assumes that understanding the relationship between tolerance of ambiguity and design performance may be beneficial to design education and the development of teaching curricula. The capacity to tolerate ambiguity can help them to cope with states of uncertainty, remain open, consider alternative and conflicting notions, and defer judgment. Developing such tolerance entails being able to accept the potential mess, incoherence, and disorder of what might emerge from the design activity. Through the design process, students will always face moments when nothing is being created. As these states are intolerable to most of them, they may try to avoid uncertainty by seeking simpler answers and giving up the struggle. Hence, our study asserts that ambiguity tolerance can be considered an important skill that needs to be cultivated for architecture students and specifically with respect to their divergent thinking ability.

\section{References}

Allwood, C. M., \& Selart, M. (Eds.). (2001). Decision making: Social and creative dimensions. Kluwer Academic Publishers. https://doi.org/10.1007/978-94-015-9827-9

Anderson, T. D. (2010, June). Kickstarting creativity: Supporting the productive faces of uncertainty in information practice. Proceedings of the $7^{\text {th }}$ International Conference on Conceptions of Library and Information Science "Unity in Diversity", Part 2 (pp. 1-14). London, United Kingdom.

Arquero, J. L., \& Tejero, C. (2009). Ambiguity tolerance levels in Spanish accounting students: A comparative study. Revista de Contabilidad, 12(1), 95-115. https://doi.org/10.1016/S1138-4891(09)70003-2

Austerlitz, N., Blythman, M., Grove-White, A., Jones, B. A., Jones, C. A., Morgan, S. A., Orr, S., Shreeve, A., \& Vaughan, S. (2008). Mind the gap: Expectations, ambiguity and pedagogy within art and design higher education. In L. Drew (Ed.), The student experience in art and design higher education: Drivers for change (pp. 125-148). Jill Rogers Associates Limited.

Ayyıldız Potur, A., \& Barkul, Ö. (2006, March). Creative thinking in architectural design education. In Proceedings of the $1^{\text {st }}$ International CIB Endorsed METU Postgraduate Conference Built Environment and Information Technologies (pp. 113-125). Ankara, Turkey. https://www.irbnet.de/daten/ iconda/06059008097.pdf

Ayyıldız Potur, A., \& Barkul, Ö. (2009). Gender and creative thinking in education: A theoretical and experimental overview. ITU Journal of the Faculty of Architecture, 6(2), 44-57.

Balgiu, B. A. (2014). Ambiguity tolerance in productional creativity. Lumen Social Sciences, III(1), 29-40. https://doi.org/10.18662/lumenss.2014.0301.02

Belluigi, D. Z. (2013). A proposed schema for the conditions of creativity in fine art studio practice. The International Journal of Arts Education, 14(18-19), 1-22. 
Buchanan, R. (1992). Wicked Problems in design thinking. Design Issues, 8(2), 5-21. https://doi.org/10.2307/1511637

Budner, N. Y. S. (1962). Intolerance of ambiguity as a personality variable. Journal of Personality, 30(1), 29-50. https://doi.org/10.1111/j.1467-6494.1962.tb02303.x

Carabine, J. (2013). Creativity, art and learning: A psycho-social exploration of uncertainty. The International Journal of Art and Design Education, 32(1), 33-43. https://doi.org/10.1111/j.1476-8070.2013.01745.x

Casakin, H. (2008). Factors of design problem-solving and their contribution to creativity. Open House International, 33(1), 46-60.

Casakin, H., \& Kreitler, Sh. (2008). Correspondences and divergences between teachers and students in the evaluation of design creativity in the design studio. Environment and Planning B: Planning and Design, 35(4), 666-678. https://doi.org/10.1068/b3405

Cash, Ph., \& Kreye, M. (2018). Exploring uncertainty perception as a driver of design activity. Design Studies, 54, 50-79. https://doi.org/10.1016/j.destud.2017.10.004

Chan, Ch.-Sh. (2015). Style and creativity in design. Series: Studies in applied philosophy, epistemology and rational ethics. Springer International Publishing. https://doi.org/10.1007/978-3-319-14017-9

Charmaz, K. (2006). Constructing grounded theory: A practical guide through qualitative analysis. Thousand Oaks, SAGE Publications.

Cho, J. Y. (2012, April). Spatial ability, creativity, and studio performance in architectural design. In T. Fischer, De K. Biswas, J. J. Ham, R. Naka, \& W. X. Huang (Eds.), Beyond Codes and Pixels. Proceedings of the $17^{\text {th }}$ International Conference on Computer-Aided Architectural Design Research in Asia (pp. 131-140). Chennai, India.

Comadena, M. E. (1984). Brainstorming groups: Ambiguity tolerance, communication apprehension, task attraction, and individual productivity. Small Group Behavior, 15(2), 251-264. https://doi.org/10.1177/104649648401500207

Daalhuizen, J., Badke-Schaub, P., \& Batill, S. M. (2009). Dealing with uncertainty in design practice: Issues for designer-centered methodology. Proceedings of ICED 09, The $17^{\text {th }}$ International Conference on Engineering Design (pp. 147-158). Palo Alto, California. file://C:/Users/1680/Downloads/ ds58_9-147.pdf

Glover, J. A., Ronning, R. R., \& Reynolds, C. R. (Eds). (2010). Handbook of creativity. Series: Perspectives on Individual Differences. Plenum Press.

Goel, V., \& Pirolli, P. (1992). The structure of design problem spaces. Cognitive Science, 16, 395-429. https://doi.org/10.1207/s15516709cog1603_3

Gonçalves, M., Cardoso, C., \& Badke-Schaub, P. (2014). What inspires designers? Preferences on inspirational approaches during idea generation. Design Studies, 35(1), 29-53. https://doi.org/10.1016/j.destud.2013.09.001

Griffin, P., \& Care, E. (Eds.). (2015). Assessment and teaching of $21^{\text {st }}$ century skills: Methods and approach. Series: Educational Assessment in an Information Age. Springer Science+Business Media. https://doi.org/10.1007/978-94-017-9395-7

Guilford, J. P. (1950). Creativity. American Psychologist, 5(9), 444-454. https://doi.org/10.1037/h0063487

Hamza, T. S., \& Hassan, D. K. (2016). Consequential creativity: Student competency and lateral thinking incorporation in architectural education. International Journal of Technology and Design Education, 26(4), 587-612. https://doi.org/10.1007/s10798-015-9321-4

Herman, J. L., Stevens, M. J., Bird, A., Mendenhall, M., \& Oddou, G. (2010). The tolerance for ambiguity scale: Towards a more refined measure for international management research. International Journal of Intercultural Relations, 34(1), 58-65. https://doi.org/10.1016/j.ijintrel.2009.09.004 
Hokanson, B., \& Gibbons, A. (Eds.). (2014). Design in educational technology: Design Thinking, design process, and the design studio. Series: Educational communications and technology: Issues and innovations. Springer International Publishing. https://doi.org/10.1007/978-3-319-00927-8

Jonassen, D. H., \& Grabowski, B. L. (1993). Handbook of individual differences: Learning and instruction. Lawrence Erlbaum Associates, Inc., Publishers.

Kim, K. H. (2011). The APA 2009 division 10 debate: Are the Torrance tests of creative thinking still relevant in the 21st century? Psychology of Aesthetics, Creativity, and the Arts, 5(4), 302-308. https://doi.org/10.1037/a0021917

Lawson, B. (2005). How designers think: The design process demystified. Routledge/Architectural Press. https://doi.org/10.4324/9780080454979

Litchfield, S. (2016, April). Negative capability in the design studio. Research Based Education, Vol. 1. International Peer Reviewed Conference AAE (pp. 338-347). London, United Kingdom.

Mack, N., Woodsong, C., MacQueen, K. M., Guest, G., \& Namey, E. (2005). Qualitative research methods: A Data collector's field guide. Family Health International.

Mahdizadeh Hakak, A., Biloria, N., \& Ahmadi Venhari, A. (2014). Creativity in architecture - A review on effective parameters correlated with creativity in architectural design. Journal of Civil Engineering and Architecture, 8(11), 1371-1379. https://doi.org/10.17265/1934-7359/2014.11.003

Merrotsy, P. (2013). Tolerance of ambiguity: A trait of the creative personality? Creativity Research Journal, 25(2), 232-237. https://doi.org/10.1080/10400419.2013.783762

Osmond, J., Bull, K., \& Tovey, M. (2009). Threshold concepts and the transport and product design curriculum: Reports of research in progress. Art, Design and Communication in Higher Education, 8(2), 169-175. https://doi.org/10.1386/adch.8.2.169/1

Runco, M. A., \& Jaeger, G. J. (2012). The standard definition of creativity. Creativity Research Journal, 24(1), 92-96. https://doi.org/10.1080/10400419.2012.650092

Sachs, A. (1999). "Stuckness" in the design studio. Design Studies, 20(2), 195-209. https://doi.org/10.1016/S0142-694X(98)00034-9

Schon, D. (1986). The design studio: An exploration of its traditions and potentials. Series: Architecture and the higher learning. International Specialized Book Services.

Stoycheva, K. (2003, April). Talent, science, and education: How do we cope with uncertainty and ambiguities? Proceedings of the NATO Advanced Research Workshop on Science Education: Talent Recruitment and Public Understanding. P. Csermely \& L. Lederman (Eds.). (pp. 31-43). Budapest, Hungary.

Tan, A.-G. (Ed.). (2007). Creativity: A handbook for teachers. World Scientific Publishing Co. Pte. Ltd. https://doi.org/10.1142/6211

Taura, T., \& Nagai, Y. (Eds.). (2011). Design creativity 2010. Springer Verlag. https://doi.org/10.1007/978-0-85729-224-7

Toh, Ch. A., \& Miller, S. R. (2016). Creativity in design teams: The Influence of personality traits and risk attitudes on creative concept selection. Research in Engineering Design, 27(1), 73-89. https://doi.org/10.1007/s00163-015-0207-y

Wallas, G. (2014). The art of thought. Solis Press.

Ward, Th. B., Finke, R. A., \& Smith, S. S. (1995). Creativity and the mind: Discovering the genius within. Plenum Publishing Corporation. https://doi.org/10.1007/978-1-4899-3330-0

Wu, X., Gu, X., \& Zhang, H. (2016). The facilitative effects of ambiguous figures on creative solution. The Journal of Creative Behavior, 53(1), 44-51. https://doi.org/10.1002/jocb.161

Zenasni, F., Besançon, M., \& Lubart, T. (2008). Creativity and tolerance of ambiguity: An empirical study. Journal of Creative Behavior, 42(1), 61-73. https://doi.org/10.1002/j.2162-6057.2008.tb01080.x 


\title{
SANTYKIS TARP TOLERANCIJOS DVIPRASMIŠKUMUI IR KÜRYBIŠKUMO ARCHITEKTŪRINIO PROJEKTAVIMO STUDIJOJE
}

\author{
Naiera Ebrahim MAHMOUD, Shaimaa Mohamed KAMEL, \\ Tamer Samir HAMZA \\ Santrauka
}

Kūrybiškumas kaip kognityvinis gebejimas sudaro sąlygas asmenims sukurti originalių ir funkcionalių idejų bei produktų. Kadangi architektūrinis projektavimas reikalauja priimti estetinius ir praktine prasme naudingus sprendimus, todèl pirmiausia reikia rūpintis kūrybiškumo stiprinimu su projektavimu susijusiose disciplinose. Dauguma teoretikų įrodinèja, kad projektavimas yra nelinijinis procesas, o didžioji dalis projektavimo problemų sudedamųjų dalių nuo pat pradžių sudaro neaiškumų. Prasidedant procesui, projektuotojai bet kuriuo atveju darbuojasi sprendimo erdvès paribyje, kuriame yra mažai darnumo, tačiau kur kas daugiau - dviprasmiškumo. Tad jiems tenka spręsti klausimus, susijusius su dideliu dviprasmiškumu bet kurioje projektavimo situacijoje. Šios netikrumo ir painiavos būsenos gali erzinti architektūros studentus. Kita vertus, tolerancija dviprasmiškumui - tai asmenybės bruožas, siejamas su kūrybiniu mąstymu. Todèl šiame straipsnyje siekiama išnagrinèti koreliaciją tarp architektūros studentų tolerancijos dviprasmiškumui ir jų kūrybiškumo, atliekant kokybinį tyrimą. Tyrèjai taikè mišrų metodą, o jų tyrimo objektu tapo 18 architektūros studentų. Šio tyrimo rezultatai atskleidè, kad yra reikšminga koreliacija tarp studentų kūrybinio mąstymo gebejjimų ir jų tolerancijos dviprasmiškumui. Rezultatai, kuriuos gavome, taip pat parodè, kad nèra statistiškai reikšmingos koreliacijos tarp studentų tolerancijos dviprasmiškumui ir to, ar jų atliekamas projektavimas yra kūrybiškas.

Reikšminiai žodžiai: architektūros studentai, kūrybiškumas, projektavimo problemos, projektavimo procesas, tolerancija dviprasmiškumui.

\section{Appendix}

Please respond to the following statements by indicating the extent to which you agree or disagree with them. Circle the number that best represents your evaluation of the item. Please be honest as possible.

SA: Strongly agree; A: Slightly agree; N: Neither agree nor disagree; D: Slightly disagree; SD: Strongly disagree:

- I avoid settings where people do not share my values (reverse coded).

- I would like to live in a foreign country for a while.

- I like to surround myself with things that are familiar to me (reverse coded).

- I can be comfortable with nearly all kinds of people.

- A good job is one where what is to be done and how it is to be done are always clear (reverse coded).

- If given a choice, I will usually visit a foreign country rather than vacation at home.

- I can enjoy being with people whose values are very different from mine. 
- What we are used to is always preferable to what is unfamiliar (reverse coded).

- A person who leads an even, regular life in which few surprises or unexpected happenings arise really has a lot to be grateful for (reverse coded).

- I like parties where I know most of the people more than ones where all or most of the people are complete strangers (reverse coded).

- The sooner we all acquire similar values and ideals the better (reverse coded).

- A good teacher is one who makes you wonder about your way of looking at things.

Note: all the items are scored on a 5 -point Likert scale, ranging from " $1=$ Strongly disagree" to " $5=$ Strongly agree" and a " $3=$ Neither agree nor disagree" option in the middle (this scoring pattern is inverted for items followed by (reverse coded), see Herman et al., 2010). 